\title{
DIGITAL TRANSFORMATION AND HUMAN RESOURCE MANAGEMENT: DIGITAL HR APPLICATION EXAMPLES OF BUSINESSES
}

\author{
DOI: 10.17261/Pressacademia.2020.1199 \\ PAP- V.11-2020(44)-p.224-225
}

\section{Selma Kilic Kirilmaz}

${ }^{1}$ Sakarya University of Applied Sciences, International Trade and Logistics, Sakarya, Turkey. email: skirilmaz@subu.edu.tr., ORCID: 0000-0002-8478-1910

To cite this document

Kilic Kirilmaz, S. (2020). Digital Transformation And Human Resources Management: Digital HR Application Examples of Businesses, PressAcademia Procedia (PAP), V.11, p. 224-225

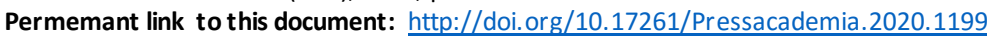

Copyright: Published by PressAcademia and limited licenced re-use rights only.

\begin{abstract}
Purpose- The purpose of this study is to reveal the effects of digital transformation in the business world on Human Resources Management practices.

Methodology- In the study, content analysis method, one of the qualitative research methods, was used. In order to collect data, searches were made under the titles "Digital Human Resources Management", "Digital Transformation HR", "Digital Transformation Human Resources Management", "Digital Business". As a result of the search, interviews and news that meet the "Digital Human Resources Applications" criteria and conducted with business managers or HR managers are included in the scope of the research. In this way, 16 (sixteen) companies formed the sample of the research. A second search was made on the websites of the companies that make up the research sample. Finally, with the name of the business and the titles of "Digital Human Resources" and "Digital HR", a search was made again and the interviews and news found were included in the research. The information obtained as a result of the searches was classified and analyzed.

Findings- As a result of the research, it has been seen that digitalization is reflected in almost all human resources applications of companies, and all human resources functions from recruitment and interview to performance and career management are transferred to digital environment. The most important digital applications are the use of chatbots, the use of QR code in job applications, mobile applications, data based analysis with dashboard, and pre-selection in recruitment by artificial intelligence.

Conclusion- It has been observed that digital transformation is closely followed by the companies examined within the scope of the research. All other businesses need to adapt their own businesses to human resources practices, being aware of this digital transformation.
\end{abstract}

Keywords: Human Resources Management, Digital HR, Digital Transformation, Digitalization, Industry 4.0.

JEL Codes: M12, M15, M54

\section{DiJiTAL DÖNÜŞÜM ve iNSAN KAYNAKLARI YÖNETIMi: IŞLETMELERIN DiJiTAL IK UYGULAMA ÖRNEKLERi}

\section{ÖZET}

Amaç- Bu çalışmanın amacı, iş dünyasında yaşanmakta olan dijital dönüşümün İnsan Kaynakları Yönetimi uygulamalarına olan etkilerinin ortaya konulmasıdır.

Yöntem- Çalışmada, nitel araştırma yöntemlerinden içerik analizi yöntemi kullanılmıştır. Verilerin toplanması amacıyla, “Dijital İnsan Kaynakları Yönetimi”, "Dijital Dönüşüm IK", "Dijital Dönüşüm İnsan Kaynakları Yönetimi”, "Dijital İşletme” başlıkları ile ara malar yapılmıştır. Yapılan aramalar neticesinde "Dijital İnsan Kaynakları Uygulamaları" kriterine uyan ve işletme yöneticileri veya İk yöneticileri ile yapılan röportaj ve haberler araştırma kapsamına alınmıştır. Bu sayede 16 (onaltı) işletme araştırmanın örneklemini oluşturmuştur. Araştırma örneklemini oluşturan işletmelerin internet sitelerinden ikinci bir tarama yapılmıştır. Son olarak işletmenin ismi ve "Dijital İnsan Kaynaklarl" ve "Dijital IK" başlıkları ile tekrar bir arama yapılarak bulunan röportaj ve haberler araştır maya dâhil edilmiştir. Aramalar neticesinde elde edilen bilgiler sınıflandırılarak analiz edilmiştir.

Bulgular- Yapılan araştırma sonucunda dijitalleşmenin işletmelerin neredeyse tüm insan kaynakları uygulamalarına yansıdığı, işe alım ve mülakattan performans ve kariyer yönetimine kadar tüm insan kaynakları fonksiyonlarının dijital ortama taşındığı görülmüştür. Chatbotların kullanımı, iş başvurularında QR kod kullanımı, mobil uygulamalar, dashboard ile veriye dayalı analizler, i̇şe alımlarda ön ele melerin yapay zekâ tarafından yapılması en önemli dijital uygulamalar olarak görülmektedir. 
Sonuç-Dijital dönüşümün araştırma kapsamında incelenen işletmeler tarafından yakından takip edildiği görülmüştür. Diğer tüm işletmelerin de bu dijital dönüşümün farkında olarak kendi işletmelerinin insan kaynakları uygulamalarına uyarlaması gerekmektedir.

Anahtar Kelimeler: İnsan Kaynakları Yönetimi, Dijital iK, Dijital Dönüşüm, Dijitalleşme, Endüstri 4.0.

JEL Kodları: M12, M15, M54 